\title{
100 YEARS INTERNATIONAL LAW ASSOCIATION (1873-1973)
}

In zwangloser Folge erhalten an dieser Stelle Institutionen, die für die Entwicklungspolitik und Entwicklungsforschung von Bedeutung sind, Gelegenheit zur Selbstdarstellung. Diesmal geben wir der International Law Association anläßlich ihres 100jährigen Bestehens das Wort.

The Centenary Celebration of the International Law Association (ILA) has taken place at Brussels from August 30th to Sept. 1st, 1973. In the same city the well known international association, wherein scholars as well as practioners collaborate in the interest of the development of International Law, has been founded in 1873 . During these 100 years the ILA developed to one of the most important legal associations. It comprises today more than 40 national groups with more than 4000 members. For the work of the association it is important that membership includes the European-American and the Socialist area as well as the states of the "Third World". Regional centers of gravity are still, inspite of this world-wide extension, in Western Europe and in the United States. One of the present tasks of the ILA will be, as Lord Wilberforce (chairman of the Executive Council and the standing secretariat of the ILA at London) emphasized in the opening ceremony at the Brussels Hotel de Ville, to enlarge the membership of the ILA mainly in the Third World.

Since its foundation the main task of the ILA has been to support the development of actual tendencies of International Law by means of co-operation between theory and practice. This purpose is served by the work of the conferences which take place every 2 years (last time New York 1972, next time New Delhi 1974) as well as the work which is done in the meantime in the various ILA committees. Their present spectrum covers nearly all actual questions of International Law, reaching from the 1st committee of "Air Law" to the latest 18th committee dealing with questions of the international protection of environment and the 19th committee of transnational societies which is still in foundation. In this way the work of the ILA constitutes a very important and fruitful alternative to the efforts of the "Institut de Droit International" which has also been established 100 years ago and which is dealing in more restricted membership mainly under scholarly aspects with questions of International Law.

The Centenary Celebration of this year at Brussels took place under the chairmanship of ILA-president Prof. Cecil Olmstead (USA) and had been organized professionally as well as socially in a most careful and magnificent way by Maître Henri Cochaux (President of the Belgian-Luxembourg branch). In 3 groups

1.) "International conflicts" (under the chairmanship of the former judge at the International Court of Justice Sir Gerald Fitzmaurice)

2.) "Liberty of the individual" (under the chairmanship of Procureur Général W. Ganshof van der Meersch)

3.) "Protection of environment" (under the chairmanship of Ambassador Mitsudeira, Sri Lanka)

important questions of present International Law were discussed with a very active and wide-spread international participation. This work will continue in the re- 
spective committees of the ILA leading thus over in the ILA working tradition to model-conventions or other practical suggestions which often influenced the state practice in the questions. involved.

From the very beginning German participation in the work of the ILA has been very active. Already among the "founding fathers" of 187.3 had been a German and a number of conferences of the ILA, mainly till the first World War, had taken place under German Presidents (for example Friedrich Sieveking, Hamburg, H. H. Meier, Bremen). The political developments after the first and second World War reduced for some time the German collaboration inside ILA, but especially the impressive Hamburg conference of 1960 under President Prof. Rolf Stödter, Hamburg, set up new standards for the German praticipation. In the meantime the German branch of the ILA (chairman Prof. Günther Jaenicke, Frankfurt) is active again participating in the committees as well as in the conferences of the association. After the re-establishment of the old German branch in 1951 in the Federal Republic of Germany, an East-German branch has been created 1968 in the German Democratic Republic (chairman Prof. Dr. Wünsche, Potsdam-Babelsberg) which has been taking part since then as an independant national group in the work of the ILA.

The successful Centenary Celebration and the continuous qualified work in the committees and during the last conferences let expect that the ILA will live up to its ideals with the same eager spirit and careful attention for the problems of modern International Law during its second century of existence as this has been the case in the past. The many new questions in International Law mainly caused by the technological and industrial development and by the emergence of the new states in the Third World with the "North-South Conflict" resulting from this, let suppose that the ILA will never be out of work in the foreseeable future!

Thomas Oppermann, Tübingen 